\title{
Poczucie tożsamości narodowej osób w wieku późnej dorosłości żyjących w polskiej i czeskiej części Śląska Cieszyńskiego
}

\begin{abstract}
Abstrakt
W artykule zaprezentowano wyniki badań dotyczące poczucia tożsamości osób w wieku późnej dorosłości żyjących w polskiej i czeskiej części Śląska Cieszyńskiego. Rozważania dotyczą szczególnego regionu ze względu na jego zróżnicowanie religijne, kulturowe, a także tradycje kształtowania wielokulturowej tożsamości. W opracowaniu ukazano wieloaspektowość pojęcia tożsamość, które rozwijane jest na gruncie filozofii, psychologii i socjologii. Tożsamość to konstrukt, który łączy elementy indywidualnego systemu wartości z wartościami danej grupy, do której jednostka należy, świadome uczestnictwo w życiu grupy regionalnej, narodowej, europejskiej i globalnej przyczynia się do kształtowania się poczucia tożsamości osób w wieku późnej dorosłości. Wyniki przeprowadzonych badań własnych wskazują, że osoby żyjące w polskiej i czeskiej części Śląska Cieszyńskiego wykazują silne więzi z narodem.
\end{abstract}

Słowa kluczowe: tożsamość narodowa, osoby w wieku późnej dorosłości, Śląsk Cieszyński.

\section{Sense of National Identity in People in Their Late Adulthood from the Polish and Czech Parts of Cieszyn Silesia}

\begin{abstract}
The paper presents the results of research into the sense of identity in people in late adulthood living in the Polish and Czech parts of Cieszyn Silesia. The discussion concerns a region which is special due to its religious and cultural diversity as well as
\end{abstract}

* Uniwersytet Śląski w Katowicach. 
traditions of forming multicultural identity. The paper presents the multi-faceted concept of identity, which is developed on the basis of philosophy, psychology and sociology. Identity is a construct which combines an individual system of values with the values of a group which an individual belongs to. A conscious participation in the life of a regional, national, European and global group contributes to forming the sense of identity in people in their late adulthood. The study results show that people in their late adulthood, who live in the Polish and Czech parts of Cieszyn Silesia, have strong bonds with their nations.

Keywords: national identity, people in their late adulthood, Cieszyn Silesia.

\section{Wstęp}

Poczucie tożsamości pojmowane jest jako naczelna wartość, rdzeń osobowości, doświadczanie swojego Ja. Człowiek dąży do poznania siebie, swoich odczuć, wyobrażeń, w drodze poszukiwania odpowiedzi na pytania o sens własnej egzystencji.

Człowiek tworzy swoją tożsamość w efekcie poszukiwań odpowiedzi na nurtujące go pytania o sens istnienia. Kształtowanie tożsamości następuje na tle innych osób oraz otaczających jednostkę grup. Człowiek dostrzegając odmienność innych, zauważa również cechy charakterystyczne tylko dla niego lub danej zbiorowości, z którą się utożsamia. Na tej podstawie tworzy swój wizerunek.

Zagadnienie kształtowania się poczucia tożsamości dzieci i młodzieży żyjącej na pograniczu polsko-czeskim było wielokrotnie podejmowane w pracach przygotowanych pod kierunkiem naukowym profesora Tadeusza Lewowickiego przez Katedrę i Zakład Pedagogiki Ogólnej Wydziału Etnologii i Nauk o Edukacji w Cieszynie Uniwersytetu Śląskiego w Katowicach oraz Społeczny Zespół Badań Kultury i Oświaty Pogranicza. W latach 1992-2013 z udziałem młodych Polaków i Czechów zamieszkujących pogranicze polsko-czeskie były wielokrotnie przeprowadzane przez cieszyński ośrodek naukowy.

Badania z udziałem osób starszych żyjących na tym pograniczu wynikają z dostrzeżenia swoistej luki w obszarze badań pogranicza, potrzeby jej wypełnienia oraz zainteresowań autorki oscylujących wokół osób w wieku późnej dorosłości. Osoby w tym wieku tworzą specyficzną grupę ze swoimi przeżyciami, emocjami oraz doświadczeniem zawodowym, warto wobec tego zastanowić się nad poczuciem tożsamości narodowej tej grupy wiekowej.

\section{Przebieg badań}

Celem podjętych poczynań badawczych jest poznanie poczucia tożsamości narodowej osób w wieku późnej dorosłości żyjących w polskiej i czeskiej części Śląska Cieszyńskiego. 
Prezentowane niżej wyniki są efektem poczynań badawczych prowadzonych na potrzeby rozprawy doktorskiej ${ }^{1}$. W badaniach wykorzystano - ankietę, zgodnie z typologią Krzysztofa Rubachy - jako metodę zbierania danych ilościowych (Rubacha 2008: 132). Kwestionariusz ankiety przygotowano w języku polskim dla osób mieszkających w polskiej części Śląska Cieszyńskiego oraz w języku czeskim dla osób mieszkających w czeskiej części Śląska Cieszyńskiego. Ogółem badaniami objęto 110 osób, badania przeprowadzone zostały w 2013 r. W kwestionariuszu ankiety zadano badanym bezpośrednie pytanie: Kim się Pani/Pan czuje? - Polakiem; Czechem; Zaolzianinem; Ślązakiem; Europejczykiem; obywatelem świata; w jednakowym stopniu każdym; zaopatrzone w kafeterie półotwartą: raczej Polakiem niż...; raczej Czechem niż...; raczej Zaolzianinem niż...; raczej Ślązakiem niż...; raczej Europejczykiem niż...; raczej obywatelem świata niż...; inna odpowiedź. Uzyskane odpowiedzi poddano analizie statystycznej.

W badaniach udział wzięły osoby w wieku późnej dorosłości. Termin późna dorosłość odnosi się do okresu starzenia się człowieka, nazywanego tradycyjnie starością. Granice tego okresu rozwojowego oscylują od 55.-60. roku życia i więcej (Harwas-Napierała, Trempała 2002: 15, 263). Na tym etapie rozwoju jednostka dokonuje podsumowania swojej egzystencji. Sytuacja taka może przyczynić się do dalszego kreatywnego rozwoju lub budowania negatywnego napięcia wynikającego $\mathrm{z}$ radzenia sobie z kryzysem tożsamości. W związku z tym interesujące wydaje się poznanie sposobów radzenia sobie tej grupy wiekowej z trudnościami w kształtowaniu tożsamości.

Teren badań nie jest przypadkowy, Cieszyn oraz Czeski Cieszyn to dwa sąsiadujące ze sobą miasta, znajdujące się na terenie historycznego Śląska Cieszyńskiego. Śląsk Cieszyński to region usytuowany w granicach Rzeczpospolitej Polskiej i Republiki Czeskiej - to miejsce styku, przenikania tradycji, obyczajów i zachowań różnorodnych grup kulturowych (Chlebowczyk 1983).

W badaniach zastosowano celowy dobór próby z populacji skończonej (Pilch, Bauman 2001). W badaniach ilościowych osób starszych zastosowano metodę doboru nielosowego - dobór celowy (w wieku późnej dorosłości), także dobór kuli śniegowej (Rubacha 2008: 231-232).

Do obróbki zebranego materiału zastosowano metody i techniki statystyczne, m.in. analizę skupień (metoda klasyfikacji przypadków lub zmiennych, łączenie drzewkowe, miary odległości) oraz analizę kanoniczną (wielowymiarowe korelacje dwóch list zmiennych, ładunki kanoniczne) (Frankfort-Nachmias, Nachmias 2001). Takie postępowanie umożliwiło całościowe ujęcie wszystkich przyjętych w tej pracy zmiennych (Ferguson, Takane 2004: 547-571). W analizie wykorzystano pakiet STATISTICA 10.

\footnotetext{
${ }^{1}$ Podejmowany temat szerzej zostaje opisany w rozprawie doktorskiej K. Jas: Poczucie tożsamości osób w wieku późnej dorosłości - studia i doświadczenia na przykładzie Ślaska Cieszyńskiego. Rozprawa doktorska napisana pod kierunkiem dr hab. A. Szczurek-Boruty, Uniwersytet Śląski, Wydział Etnologii i Nauk o Edukacji w Cieszynie.
} 
Dla szacowania związków pomiędzy wybranymi zbiorami zmiennych wykorzystano analizę kanoniczną (Ferguson, Takane 2004: 532-533). Dla dwóch zbiorów zmiennych określano wagi maksymalizujące korelację między sumą wyników ważonych dla tych zbiorów. Pierwiastki kwadratowe z wartości własnych interpretowane są jako współczynniki korelacji kanonicznych.

Zastosowano jedną z metod tzw. klasyfikacji - metodę taksonomiczną, statystyczną - analizę skupień. Pozwoliła ona na grupowanie zachowań we względnie jednorodne klasy. W wyniku aglomeracji uzyskano hierarchiczne wykresy drzewkowe. Jeśli istnieją skupienia podobnych do siebie obiektów, to struktura ta znajduje odbicie na hierarchicznym drzewie w postaci oddzielnych gałęzi. Do łączenia (wiązania) obiektów wykorzystano metodę średnich połączeń ważonych. Odległość między obiektami wyznaczana była jako 1-r Pearsona (współczynnik korelacji liniowej) (Ferguson, Takane 2004).

\section{Poczcie tożsamości - rozważania teoretyczne}

Ze względu na wieloznaczność terminu tożsamość trudno dokonać jednoznacznego zdefiniowania tego pojęcia, gdyż z jednej strony tożsamość związana jest $\mathrm{z}$ „autopercepcją jednostki, z drugiej - z postrzeganiem innego, jak też z identyfikacją z określoną grupą oraz z przypisaniem do grupy przez innych" (Nikitorowicz 2007: 754).

Teorie dotyczące pojęcia tożsamości rozwijane są na gruncie filozofii, psychologii i socjologii. Tak szerokie ujęcie omawianego zagadnienia zwraca uwagę na jego wieloaspektowość.

W ujęciu filozoficznym istnieją dwie tradycje definiowania tożsamości - pierwsza (reprezentowana m.in. przez Kartezjusza, Kanta) pojmowała tożsamość jako ukrytą „istotę” człowieka, będącą jednocześnie wspólną całemu rodzajowi ludzkiemu, druga natomiast (przedstawicielami byli m.in. Nietzsche, Heidegger, Sartre) traktowała to samo pojęcie jako wynalazek czy budowę, konstruowane przez wybór i decyzję, a potem konsekwentną realizację projektu. Tomasz Bajkowski zauważa, że obie tradycje „są zgodne, że tożsamość nie jest dana człowiekowi od razu, lecz należy szukać jej w przeciągu całego życia, uczynić ją przedmiotem poszukiwań codziennej ludzkiej aktywności" (Bajkowski 2001: 75).

Mówiąc o tożsamości, należy mieć na uwadze dwa wymiary natury ludzkiej: indywidualny i społeczny. Zdaniem Tołwińskiej

Tożsamość społeczna wyraża się w akceptacji przynależności do danej kategorii osób, a tożsamość indywidualna to poczucie odrębności od innych oraz poczucie stabilności własnych cech. Poczucie tożsamości pełni najbardziej istotną rolę w psychologicznym wymiarze funkcjonowania człowieka, jej utrata bowiem dezorganizuje osobowość (Tołwińska 2001: 71). 
Z kolei w koncepcjach psychologicznych tożsamość ujmowana jest, jak zauważa Bugajska (2012), „głównie podmiotowo, jako rodzaj poczucia własnej odrębności, niepowtarzalności" (Bugajska 2012: 58).

Wobec tego tożsamość rozumiana jest jako wizja własnej osoby, tego z czym lub kim dana jednostka się identyfikuje, w jaki sposób postrzega siebie na tle innych jednostek lub grup. Zdaniem Władysława Misiaka

Tożsamość grupowa w swym pierwotnym wymiarze wywodzi się z potrzeby afiliacji, a więc z potrzeby przynależności. Potrzeba przynależności może być zaspokajana nie tylko w małych grupach, np. w rodzinie czy grupie towarzyskiej, lecz również większych strukturach, takich jak wspólnota regionalna czy narodowa (Misiak 2005: 84).

Według Marii Jarymowicz (1989) tożsamość to obraz własnej osoby,

a dokładnie wizje tego, co dla autocharakterystyki najważniejsze, najbardziej charakterystyczne i specyficzne. Dla wielu badaczy pojęcie tożsamości jest różnie definiowane w zależności od celów badawczych, orientacji filozoficznych i epistemologicznych (Jarymowicz 1989:73; podaję za: Suska 2001: 112).

Ujęcie socjologiczne łączy dwa poziomy funkcjonowania tożsamości, wymieniając dodatkowo tożsamość kulturową. Zdaniem Hanny Mamzer (2001) te dwa poziomy są niezbędne, aby można było mówić o tożsamości kulturowej. System norm i wartości oraz sposób ich interpretowania przez daną grupę wymaga spójności, ciągłości oraz stałości. Zapewnia to jednostce poczucie stabilizacji, bezpieczeństwa, pozwala na określenie cech, z którymi człowiek się identyfikuje. Kultura tworzona jest przez grupę, natomiast grupę tworzą jednostki, w związku z tym nie możemy mówić o tożsamości kulturowej bez podkreślania znaczenia tożsamości społecznej i jednostkowej.

H. Mamzer zwraca uwagę, że tożsamość kulturowa to:

konstrukt łączący dwa poziomy funkcjonowania - poziom jednostkowy (do którego bardziej odnosi się samo pojęcie tożsamości rozumianej jako poczucie stałości, spójności i ciągłości) i poziom społeczny, do którego nawiązuje pojęcie kultury rozumianej jako system norm i wartości i sposobów interpretowania rzeczywistości akceptowanych przez daną grupę (Mamzer 2001: 81).

W opinii socjologów należy zwrócić również uwagę na tożsamość narodową. Zdaniem Antoniny Kłoskowskiej

charakteryzując tożsamość narodową należy pytać o miejsce, rolę i funkcję narodowej identyfikacji i przyswojenia narodowej kultury w całej, 
totalnej tożsamości z usytuowania w obrębie różnorodnych czynników, z każdego czerpiąc pewne elementy swego samookreślenia i łącząc je z psychicznymi czynnikami. Przyswojenie drogą kulturalizacji określonej kultury narodowej nie wyczerpuje możliwości kształtowania poczucia wyobrażonej wspólnoty, europejskiej, globalnej (Kłoskowska 1996: 104, 110).

Na gruncie pedagogiki tożsamość rozpatrywana jest jako cel, zadanie wychowania i kształcenia - podstawowych działań pedagogicznych wspierających jednostkę w jej rozwoju.

Krzysztof Rubacha (2004) twierdzi, że oscylowanie nauczycieli i uczniów pomiędzy skrajami dostępnych światów kulturowych i sytuacji edukacyjnych w wymiarze ich lokalnego funkcjonowania przyczynia się do rozwoju tożsamości. „Efektem takich działań jest tożsamość oparta na zróżnicowanych odniesieniach i identyfikacjach, przez co bogatsza, choć sytuacyjnie trudniejsza do osiągnięcia" (Rubacha 2004: 65). Wychowanek tworzy swoją tożsamość poprzez nabywanie doświadczenia w zróżnicowanym kulturowo świecie. „Wychowanie jest poszukiwaniem symbiozy pomiędzy tożsamością wyjściową a tożsamościami zróżnicowanych światów kulturowych, w których przyszło żyć współczesnemu człowiekowi" (tamże: 66).

Jerzy Nikitorowicz uważa, że pojęcie tożsamości nierozerwalnie związane jest z potrzebą przynależności. Przynależenie do danej grupy czy zbiorowości, w ciągu całego życia, zapewnia jednostce poczucie bezpieczeństwa, pogłębianie bliskości z rodziną, przyjaciółmi i znajomymi. Akceptacja ze strony grupy daje poczucie stabilizacji oraz zakorzenienia, co przyczynia się do wzrostu poczucia własnej wartości jednostki. Nikitorowicz podkreśla, że

Identyfikowanie się jednostki z dziedzictwem grupy, jej dorobkiem i symbolami nadaje sens poczuciu przynależności. Identyfikacja czy samoidentyfikacja wymaga właśnie istnienia innych, w relacji do których możemy się określić, wskazać na odrębności kulturowe. Tam, gdzie mamy do czynienia z wielością grup, co związane jest tym samym z wielością tożsamości, pojawia się problem granicy etnicznej i świadomość dystansu, jaki dzieli od siebie odrębne grupy (Nikitorowicz 1995: 86).

Stykanie się z innymi grupami, narodowymi, etnicznymi, odmienną kulturą oraz tradycją wyzwala w jednostce „potrzebę samookreślenia się, ciągłego definiowania siebie w kontekście kontaktu z Innym" (Szczurek-Boruta 2014: 183).

Problemy z kształtowaniem się poczucia tożsamości mogą mieć osoby, które przynależą do różnych grup, żyją w różnych epokach, są świadkami przemian w dziedzinach gospodarki, polityki, kultury, oświaty, medycyny. Do takiej grupy należą osoby w wieku późnej dorosłości. Tę grupę wiekową, jak twierdzi Beata Bugajska, można uznać za 
świadków przechodzenia od społeczeństwa preindustrialnego do industrialnego i postindustrialnego, od społeczeństwa „sterowanego tradycją" do społeczeństwa „wewnątrzsterownego” i „zewnątrzsterownego”, od kultury „postfiguratywnej” do „kofiguratywnej” i „prefiguratywnej”, od „nowoczesności” do ponowoczesności”, od „świata losu” do „świata wyboru" (Bugajska 2012: 55).

Dynamika świata powoduje wiele problemów związanych z dokonywaniem wyborów, takie problemy mogą pojawić się również w okresie starości.

Początek starości często kojarzony jest z momentem przejścia na emeryturę, wówczas człowiek znajduje się w trudnym momencie swojego życia, analizuje dotychczasowy jego przebieg, szuka nowych możliwości. Dokonywane podsumowania życia mogą doprowadzić jednostkę do odkrycia sensu egzystencji lub wręcz przeciwnie - utwierdzeniu się w przeświadczeniu o bezsensowności własnego losu. W ujęciu Erika H. Eriksona (1994) sytuacja taka może przyczynić się do integracji, potwierdzenia własnej tożsamości lub doprowadzić do rozpaczy i rezygnacji z własnej tożsamości. Na potrzeby niniejszego opracowania posłużono się ujęciem poczucia tożsamości w rozumieniu E. H. Eriksona, który zauważa, że „poczucie tożsamości obejmuje sposoby świadomego doświadczania dostępnego introspekcji, sposoby zachowywania się oraz nieświadome stany wewnętrzne obserwowane przez innych" (Erikson 2000: 52).

Obszar pograniczy jest szczególnym miejscem kształtowania się tożsamości jednostki, w specyficznych warunkach kulturowych zauważalne są „przenikanie, krzyżowanie się, autonomia, stabilność, konserwatyzm, ale i symbioza, wzajemna egzystencja" (Nikitorowicz 2000: 62) osób żyjących na tych terenach.

\section{Poczucie tożsamości osób w wieku późnej dorosłości żyjących w polskiej części Śląska Cieszyńskiego na tle wyników badań własnych}

W przypadku badanych seniorów mamy do czynienia ze środowiskiem pogranicza terytorialnego i społeczno-kulturowego. Tożsamość budowana jest na podstawie wiedzy na temat grupy, do której jednostka przynależy, jej tradycji, historii. Na podstawie kontaktu z inną grupą jednostka dokonuje samooceny, a co za tym idzie utrwalania własnych norm i wartości. Twórca teorii tożsamości społecznej Henri Tajfel (1972) twierdzi, że „tożsamość społeczna wynika z wiedzy jednostki co do tego, iż należy ona do pewnych grup wraz ze znaczeniem emocjonalnym i wartością przypisywaną członkostwu grupowemu" (Kwiatkowska 1999: 86).

Wyniki przeprowadzonych badań osób w wieku późnej dorosłości zamieszkujących polską część Śląska Cieszyńskiego wskazują na silne więzi z narodem. Zdecydowana większość osób starszych czuje się członkiem grupy narodowej - 
Polakiem (85,3\%), 34,7\% badanych czuje się Ślązakiem, 29,3\% - Europejczykiem, 9,3\% respondentów stwierdziło, że czuje się obywatelem świata, a 1,3\% badanych czuje się w jednakowym stopniu każdym.

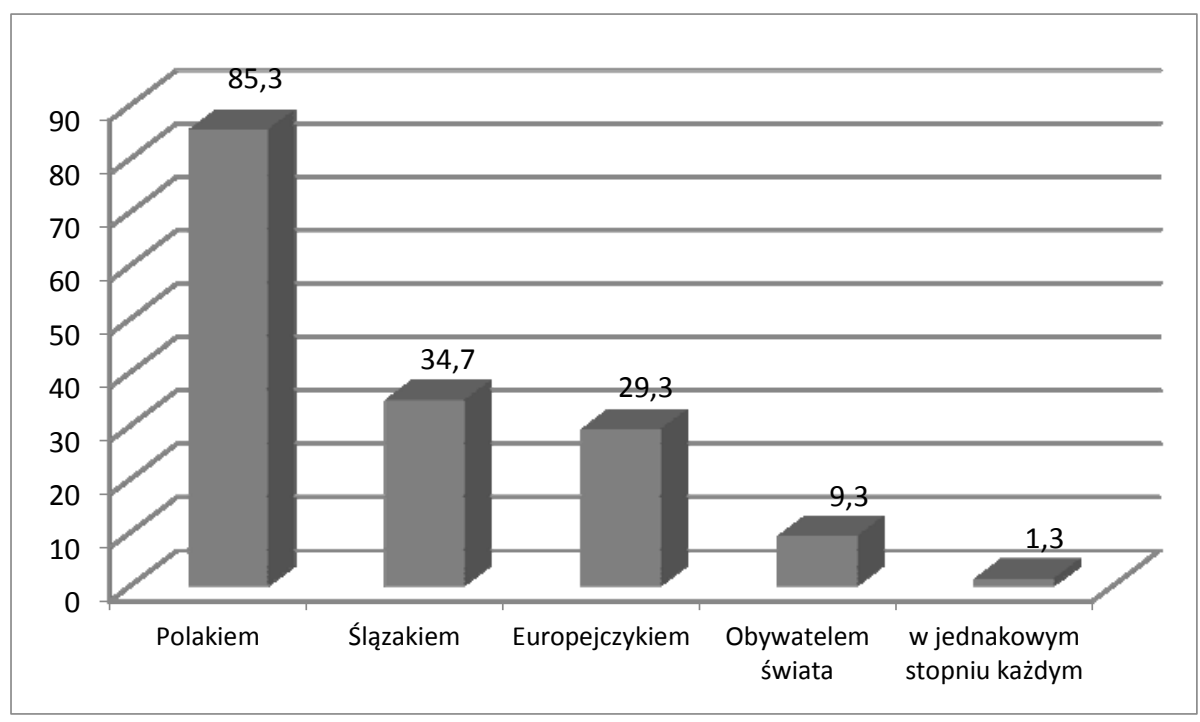

Ryc. 1. Poczucie tożsamości osób w wieku późnej dorosłości żyjących w polskiej części Śląska Cieszyńskiego

Źródło: badania własne.

Na poczucie tożsamości społecznej - jak piszą Alina Szczurek-Boruta oraz Barbara Grabowska - składa się

zjawisko, polegające na pomniejszaniu różnic pomiędzy osobami uznawanymi za reprezentantów własnej zbiorowości oraz przecenianiu różnic pomiędzy osobami zakwalifikowanymi do własnej i innych grup (Szczurek-Boruta, Grabowska 2009: 24).

Wskaźnikiem odrębności i więzi ze wspólnotą narodową jest przekonanie o silnej identyfikacji narodowej.

Nikitorowicz podkreśla, że etap utrwalania identyfikacji narodowej „realizuje się na bazie dziedzictwa rodzinno-lokalnego, regionalnego" (Nikitorowicz 2004: 119-153). Literatura przedmiotu zakłada, że najistotniejszą płaszczyzną, która chroni niezależność jednostki jest kultura narodowa. Uzyskanie owej odrębności i autonomii w myśl Teorii Zachowań Tożsamościowych Tadeusza Lewowickiego (1994), „pozwala społecznościom i jednostkom realizować własne dążenia i wyzwala określone działania społeczne zarówno o charakterze indywidualnym, jak i zbiorowym" (Szczurek-Boruta, Grabowska 2009: 31). W poczynaniach badawczych podjęto próbę ustalenia wyznaczników identyfikacji narodowej. 
Tabela 1. Dominujące kategorie pozwalające nazwać kogoś Polakiem (w \%)

\begin{tabular}{|l|c|}
\hline \multicolumn{1}{|c|}{ Kategorie } & PL \\
\hline Polskie obywatelstwo & 57,33 \\
\hline Miejsce urodzenia & 52,00 \\
\hline Pochodzenie & 50,67 \\
\hline Znajomość polskiej kultury i historii & 46,67 \\
\hline Biegłe władanie językiem polskim & 36,00 \\
\hline Miejsce zamieszkania & 32,00 \\
\hline Sentyment do kraju pochodzenia & 8,00 \\
\hline Polskie pochodzenie współmałżonka & 1,33 \\
\hline Inne & 0,00 \\
\hline
\end{tabular}

Objaśnienia: PL - osoby w wieku późnej dorosłości żyjące w polskiej części Śląska Cieszyńskiego; odpowiedzi nie sumują się do $100 \%$ ze względu na możliwość udzielenia więcej niż jednej odpowiedzi.

Źródło: badania własne.

Wśród czynników decydujących o polskiej identyfikacji narodowej badani wskazywali kolejno na polskie obywatelstwo 57,33\% oraz miejsce urodzenia $52,00 \%$. 50,67\% respondentów jako wyznacznik identyfikacji narodowej wybrało pochodzenie. Znaczące miejsce wśród determinantów identyfikacji narodowej zajmuje znajomość polskiej kultury i historii $(46,67 \%)$.

Biegłe władanie językiem polskim wskazało jako czynnik decydujący o ich identyfikacji narodowej 36,00\% badanych. W literaturze przedmiotu język postrzegany jest jako „podstawowy składnik kultury narodowej, może być traktowany jako jeden z podstawowych kryteriów przynależności narodowej” (Sadowski 1997: 98).

Miejsce zamieszkania wskazało 32,00\% badanych, natomiast sentyment do kraju pochodzenia 8,00\%.

Uzyskanie odpowiedzi na pytanie „Kim jestem”? stanowią podstawę do formułowania własnego Ja. „Identyfikacja jest najbardziej wyrazistym - jak zauważa Mirosław Sobecki - i najczęściej analizowanym wymiarem tożsamości. Rdzeniem tożsamości narodowej jest właśnie narodowa identyfikacja” (Sobecki 2007: 217). Autor ten definiuje poczucie tożsamości narodowej jako „element struktury Ja, będący nieredukowalnym, krańcowo subiektywnym, symptomem świadomości narodowej” (tamże). Identyfikacja narodowa „umożliwia wyjścia na pogranicza własnej kultury z motywacją do otwarcia i poznania innych kultur" (Szczurek-Boruta, Grabowska 2009: 32). 
W badaniach zastosowano jedną z metod tzw. klasyfikacji statystycznej (metodę taksonomiczną) - analizę skupień. Pozwoliła ona na grupowanie stwierdzeń we względnie jednorodne klasy. W wyniku aglomeracji uzyskano hierarchicznie wykresy drzewkowe. Jeśli istnieją skupienia podobnych do siebie obiektów, to struktura ta znajduje odbicie na hierarchicznym drzewie w postaci oddzielnych gałęzi. Do łączenia (wiązania) obiektów wykorzystano metodę średnich połączeń ważonych. Odległość między obiektami wyznaczana była jako 1-r Pearsona (współczynnik korelacji liniowej) (Ferguson, Takane 2004).

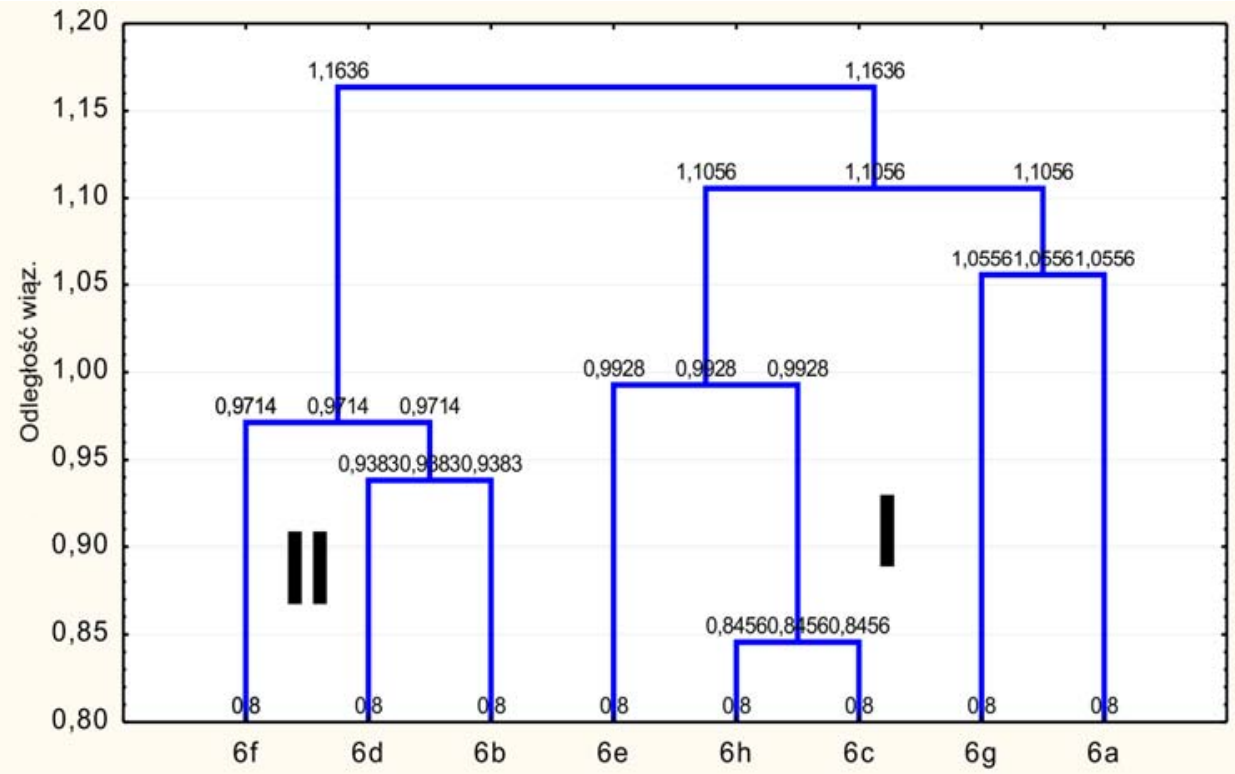

Ryc. 2. Wyznaczniki poczucia polskiej tożsamości narodowej: diagram drzewa średnich połączeń ważonych, 1-r Pearsona, warunek uwzględnia V1 = 1

Objaśnienia:

6a miejsce urodzenia

6b miejsce zamieszkania

$6 c$ biegłe władanie językiem polskim

$6 \mathrm{~d}$ polskie obywatelstwo 6e znajomość polskiej kultury i historii

6 fentyment do kraju pochodzenia

$6 \mathrm{~g}$ pochodzenie

6h polskie pochodzenie współmałżonka

Źródło: badania własne.

Analizując strukturę skupień cech pozwalających nazwać kogoś Polakiem, można dostrzec ukonstytuowanie się dwóch zasadniczych struktur. Zależności korelacyjne, jakie wystąpiły między poszczególnymi zmiennymi w pierwszej strukturze (subiektywnej/nieformalnej) w swoisty sposób ją zhierarchizowały. Najwyższą współzależność należy odnotować w odniesieniu do substruktury obejmującej: „biegłe władanie językiem polskim” (6c) oraz „polskie pochodzenie współmałżon- 
ka" (6h). Zmienne te korelowały ze sobą na słabym poziomie $(r=0,1544)^{2}$. Współtworzą one skupienie ze zmienną wskazującą na „znajomość polskiej kultury i historii" (6e), $r=0,0072$ (korelacja słaba). Powiązane są one również z kolejną substrukturą obejmującą „pochodzenie” (6g) oraz „miejsce urodzenia” (6a).

Drugą wyraźną strukturę (obiektywną, formalną) tworzą „polskie obywatelstwo” (6d) i „miejsce zamieszkania” (6b). Siła tego związku ( $r=0,0617$ ) wskazuje na korelację słabą. Tak ukonstytuowaną przestrzeń dopełnia „sentyment do kraju pochodzenia" (6f), $r=0,0286$ (korelacja słaba).

Korelacja między strukturami pierwszą i drugą ma charakter ujemny ( $\mathrm{r}=-0,1636$ ). Zważywszy jednak na nieznaczną siłę związku występującego między zmiennymi, można sądzić, że nie ma on większego znaczenia dla hierarchii wyznaczników poczucia polskiej tożsamości narodowej.

W prowadzonych analizach nie sposób pominąć identyfikacji z regionem, która odgrywa istotną rolę zarówno w kształtowaniu poczucia tożsamości narodowej, jak i innych płaszczyzn tożsamości wielowymiarowej.

Sprzyjające warunki do tworzenia się tożsamości to takie, w których jednostka czuje się najpewniej, z którymi jest najsilniej związana emocjonalnie. Dla jednostki w kształtowaniu się poczucia tożsamości duże znaczenie odgrywa więź z ojczyzną lokalną oraz regionem. Ojczyzna lokalna czy ojczyzny prywatne to pojęcia używane przez Stanisława Ossowskiego w celu określenia terytorium mającego dla jednostki wydźwięk emocjonalny.

To terytorium, na którym jednostka nie musi zamieszkiwać, ale z jakiś powodów czuje się z nim związana emocjonalnie. Należy podkreślić, że tożsamość narodowa nie tylko zawsze wyrasta $\mathrm{z}$ tożsamości niższego poziomu (lokalnej, regionalnej), ale także zawsze jakoś jest z tą niższego rzędu tożsamością powiązana (Jasiński, Kozłowska 1997). Na podstawie uzyskanych wyników badań można wskazać na swoistą hierarchię czynników wyznaczających identyfikację badanych osób starszych z regionem - ze Śląskiem Cieszyńskim. Respondenci najczęściej wskazywali na miejsce zamieszkania (61,33\%), kolejne miejsca w hierarchii zajęły: znajomość kultury i historii Śląska Cieszyńskiego (57,33\%) oraz miejsce urodzenia (52,00\%). 48,00\% badanych wymieniło pochodzenie jako czynnik identyfikacji ze Śląskiem Cieszyńskim. Biegłe władanie gwarą jako czynnik identyfikacji wskazało $28 \%$ respondentów. Podkreślić należy, że na badanym terenie „gwara jako odmiana danego języka stanowi element kultury regionalnej” (Szczypka-Rusz 2000: 51).

W opinii $26,67 \%$ osób o identyfikacji świadczy sentyment do środowiska lokalnego, regionu. Najmniejszy udział w kształtowaniu się identyfikacji ze Śląskiem Cieszyńskim przypisują badani pochodzeniu współmałżonka (4,00\%).

\footnotetext{
${ }^{2}$ Interpretacja wielkości współczynników korelacji r wg J. P. Guilforda. Poniżej 0,20 - korelacja słaba, zależność prawie nic nieznacząca; 0,20-0,40 - korelacja niska, zależność wyraźna, lecz mała; 0,40-0,70 - korelacja umiarkowana, zależność istotna; 0,70-0,90 - korelacja wysoka, zależność znacząca; 0,90-1,00 - korelacja bardzo wysoka, zależność bardzo pewna.
} 
Tabela 2. Dominujące kategorie pozwalające nazwać kogoś członkiem społeczności Śląska Cieszyńskiego (w \%)

\begin{tabular}{|l|c|}
\hline \multicolumn{1}{|c|}{ Kategorie } & PL \\
\hline Miejsce zamieszkania & 61,33 \\
\hline Znajomość kultury i historii Śląska Cieszyńskiego & 57,33 \\
\hline Miejsce urodzenia & 52,00 \\
\hline Pochodzenie & 48,00 \\
\hline Biegłe władanie gwarą & 28,00 \\
\hline Sentyment do środowiska lokalnego/regionu & 26,67 \\
\hline Pochodzenie współmałżonka & 4,00 \\
\hline Inne & 1,33 \\
\hline
\end{tabular}

Objaśnienia: PL - osoby w wieku późnej dorosłości żyjące w polskiej części Śląska Cieszyńskiego; odpowiedzi nie sumują się do $100 \%$ ze względu na możliwość udzielenia więcej niż jednej odpowiedzi.

Źródło: badania własne.

Mała Ojczyzna, jako region najbliższy człowiekowi, staje się coraz bardziej zróżnicowana. Z jednej strony sytuacja taka przyczynia się do zagrożenia poczucia bezpieczeństwa, z drugiej strony motywuje do podejmowania większych starań, wysiłków o jej integrację. „Kontakty między reprezentantami odmiennych kultur często nie należą do łatwych, rodzą konflikty, ale też jest wiele okazji do wymiany, zapożyczeń, dialogu, tolerancji, negocjowania, przekraczania granic własnej kultury" (Szczurek-Boruta 2014: 40).

\section{Poczucie tożsamości osób w wieku późnej dorosłości żyjących w czeskiej części Śląska Cieszyńskiego}

Tożsamość osób w wieku późnej dorosłości mieszkających w czeskiej części Śląska Cieszyńskiego kształtowały różne czynniki polityczne, historyczne, kulturowe, ale również indywidualne i społeczne potrzeby. Dominuje w tej grupie identyfikacja z polskością (51,4\% osób), 37,1\% badanych deklaruje, że czuje się Czechem. Wyniki przeprowadzonych badań wskazują na to, że wśród badanych osób w wieku późnej dorosłości żyjących w czeskiej części Śląska Cieszyńskiego znajduje się liczna grupa osób o polskich korzeniach, są to zapewne potomkowie autochtonicznej ludności polskiej. 28,6\% respondentów postrzega siebie jako Zaolzianina (określenie Zaolzianin odnosi się do identyfikacji regionalnej osób w wieku późnej dorosłości obywatelstwa czeskiego, narodowości polskiej, żyjących w Czechach - na Zaolziu), 
Europejczykiem czuje się 25,7\% osób, Ślązakiem 14,3\%, 8,6\% respondentów postrzega się jako obywatel świata, natomiast 2,9\% czuje się $\mathrm{w}$ jednakowym stopniu każdym.

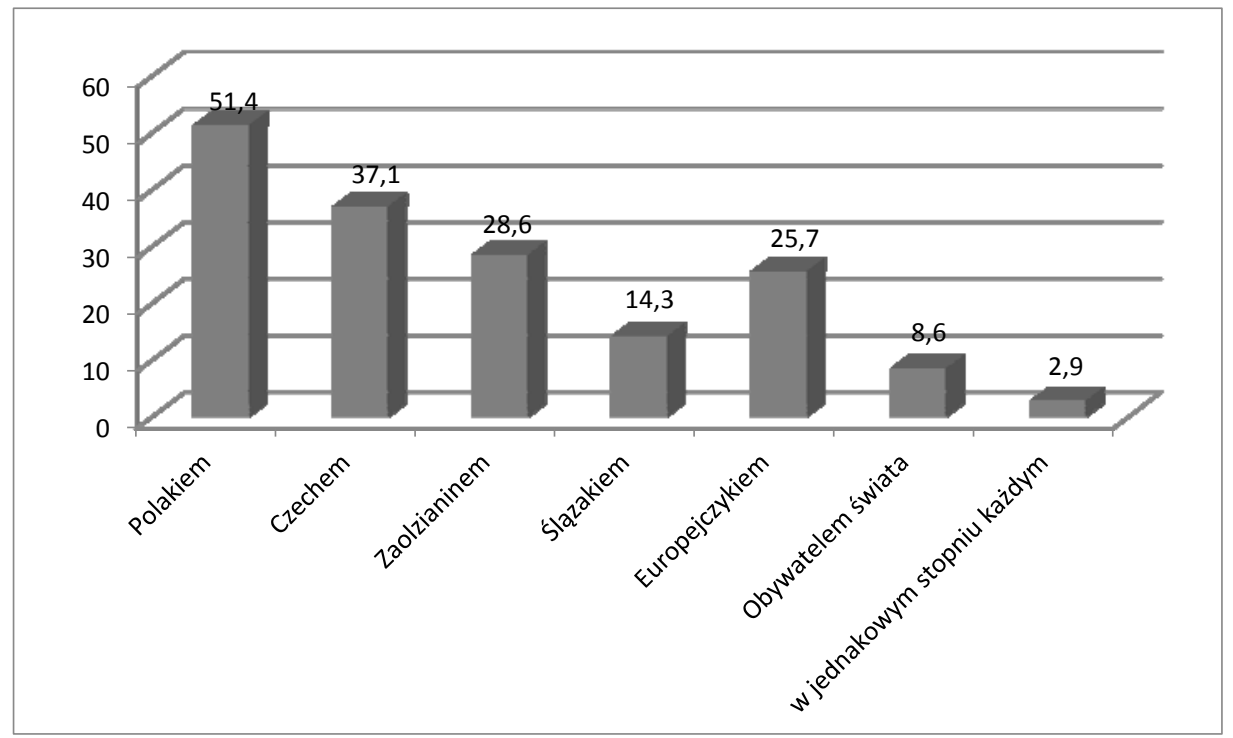

Ryc. 3. Poczucie tożsamości osób w wieku późnej dorosłości żyjących w czeskiej części Śląska Cieszyńskiego

Źródło: badania własne.

Poczucie tożsamości lokalnej osób w wieku późnej dorosłości - jak zauważa w odniesieniu do grupy młodzieży A. Szczurek-Boruta - jest „zapewne wynikiem dobrze zachowanych i utrwalonych w świadomości mieszkańców pogranicza polsko-czeskiego więzi społecznych oraz efektem prowadzonej od lat edukacji regionalnej" (Szczurek-Boruta 2009: 247).

Poniższa tabela przedstawia cechy determinujące poczucie identyfikacji narodowej mieszkańców czeskiej części Śląska Cieszyńskiego.

Czynnikiem wyznaczającym czeską identyfikację narodową dla 46,57\% osób w wieku późnej dorosłości jest czeskie obywatelstwo. Zauważyć można, że dla osób w wieku późnej dorosłości mieszkających w czeskiej części Śląska Cieszyńskiego identyfikację narodową w równym stopniu wyznaczają miejsce urodzenia oraz znajomość czeskiej kultury i historii (po 45,71\%). Znaczące miejsce w opinii respondentów zajmuje również biegłe władanie językiem czeskim oraz pochodzenie (po 42,86\%). Dla części badanych miejsce zamieszkania $(20,00 \%)$ oraz sentyment do kraju pochodzenia $(17,14 \%)$ są cechami, które pozwalają nazwać kogoś Czechem. 
Tabela 3. Dominujące kategorie pozwalające nazwać kogoś Czechem - deklaracje mieszkańców czeskiej części Śląska Cieszyńskiego (w \%)

\begin{tabular}{|l|c|}
\hline \multicolumn{1}{|c|}{ Kategorie } & CZ \\
\hline Czeskie obywatelstwo & 46,57 \\
\hline Znajomość czeskiej kultury i historii & 45,71 \\
\hline Miejsce urodzenia & 45,71 \\
\hline Pochodzenie & 42,86 \\
\hline Biegłe władanie językiem czeskim & 42,86 \\
\hline Miejsce zamieszkania & 20,00 \\
\hline Sentyment do kraju pochodzenia & 17,14 \\
\hline Inne & 5,71 \\
\hline Czeskie pochodzenie współmałżonka & 2,86 \\
\hline
\end{tabular}

Objaśnienia: CZ - osoby w wieku późnej dorosłości żyjące w czeskiej części Śląska Cieszyńskiego; odpowiedzi nie sumują się do $100 \%$ ze względu na możliwość udzielenia więcej niż jednej odpowiedzi.

Dla szacowania związków pomiędzy zbiorami zmiennych wykorzystano analizę skupień (metodę klasyfikacji przypadków lub zmiennych, łączenie drzewkowe, miary odległości) (Ferguson, Takane 2004: 532-533). Wyniki przeprowadzonej analizy statystycznej wyznaczników poczucia czeskiej tożsamości narodowej w obrazie cech, które pozwalają nazwać kogoś Czechem wskazują dwie struktury. W pierwszej najwyższą współzależność odnotować należy w odniesieniu do „sentymentu” (6f) oraz „czeskiego pochodzenia współmałżonka” (6h). Siła tego związku ( $\mathrm{r}=0,3761)$ wskazuje na korelację niską, zależność wyraźną, lecz małą. Uzupełnia tę przestrzeń „miejsce urodzenia” (6a), r = 0,1832 korelacja słaba, zależność prawie nieznacząca. Poboczne miejsce w stosunku do opisanej substruktury zajmują „biegłe władanie językiem czeskim” (6c), $r=0,0592$ korelacja umiarkowana, zależność istotna oraz pochodzenie $(6 \mathrm{~g}), \mathrm{r}=0,0136$ korelacja słaba, zależność prawie nic nieznacząca.

Drugą strukturę tworzą „miejsce zamieszkania” (6b) i „czeskie obywatelstwo” (6d), $r=0,3637$ korelacja niska, zależność wyraźna, lecz mała. Ta substruktura jest związana ze znajomością „czeskiej kultury i historii” (6e), r = 0,0654 korelacja umiarkowana, zależność istotna. Struktury pierwsza i druga pozostają w mało istotnej (nieznacznej) statystycznie zależności $(r=-0,0704)$. Korelacja między strukturami pierwszą i drugą ma charakter ujemny. Zważywszy jednak na nieznaczną siłę związku występującego między zmiennymi, można sądzić, że nie ma on większego znaczenia dla hierarchii wyznaczników poczucia polskiej tożsamości narodowej. 


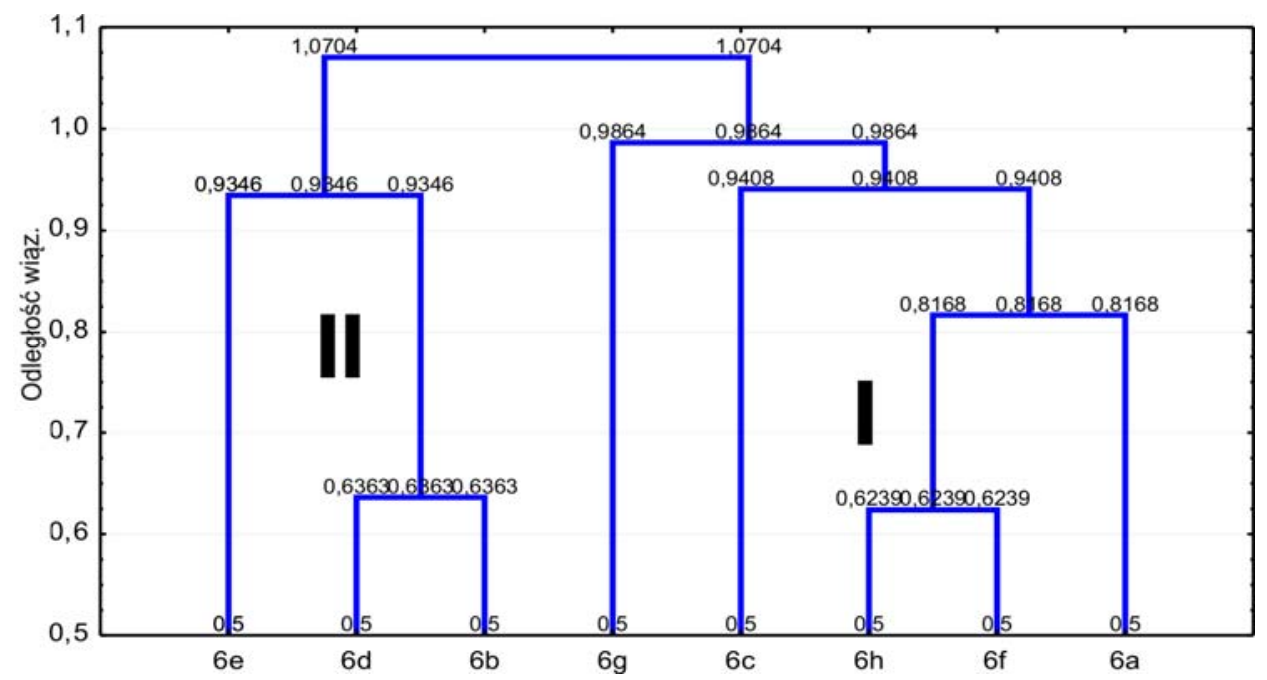

Ryc. 4. Wyznaczniki poczucia czeskiej tożsamości narodowej: diagram drzewa średnich połączeń ważonych, 1-r Pearsona, warunek uwzględnia V1 = 2

Objaśnienia:

6a miejsce urodzenia 6b miejsce zamieszkania 6c biegłe władanie językiem czeskim $6 \mathrm{~d}$ czeskie obywatelstwo

6e znajomość czeskiej kultury i historii $6 \mathrm{f}$ sentyment do kraju pochodzenia $6 \mathrm{~g}$ pochodzenie 6h czeskie pochodzenie współmałżonka

Źródło: badania własne.

Tabela 4. Dominujące kategorie pozwalające nazwać kogoś członkiem społeczności Śląska Cieszyńskiego (w \%)

\begin{tabular}{|l|c|}
\hline \multicolumn{1}{|c|}{ Kategorie } & CZ \\
\hline Znajomość kultury i historii Śląska Cieszyńskiego & 57,14 \\
\hline Miejsce urodzenia & 48,51 \\
\hline Miejsce zamieszkania & 42,86 \\
\hline Pochodzenie & 42,86 \\
\hline Biegłe władanie gwarą & 37,14 \\
\hline Sentyment & 8,57 \\
\hline Inne & 2,86 \\
\hline Pochodzenie współmałżonka & 0,00 \\
\hline
\end{tabular}

Objaśnienia: CZ - osoby w wieku późnej dorosłości żyjące w czeskiej części Śląska Cieszyńskiego; odpowiedzi nie sumują się do $100 \%$ ze względu na możliwość udzielenia więcej niż jednej odpowiedzi.

Źródło: badania własne. 
Respondenci mieszkający w czeskiej części Śląska Cieszyńskiego wśród czynników decydujących o identyfikacji ze Śląskiem Cieszyńskim najczęściej wskazywali na znajomość kultury i historii Śląska Cieszyńskiego $(57,14 \%)$, kolejne miejsca w hierarchii zajęły: miejsce urodzenia $(48,51 \%)$ oraz miejsce zamieszkania oraz pochodzenie (po 42,86\%). 37,14\% badanych wymieniło biegłe władanie gwarą jako czynnik identyfikacji ze Śląskiem Cieszyńskim. Sentyment jako czynnik identyfikacji wskazało 8,57\% respondentów. Nikt z respondentów nie wskazał na pochodzenie współmałżonka jako wyznacznik kształtujący identyfikację ze Śląskiem Cieszyńskim.

Jak twierdzi B. Grabowska, „tożsamość regionalna wiąże się z pozytywnym obrazem własnym i grupy odniesienia, w której jednostki znajdują oparcie. Jest ona także źródłem spójności i zarazem bodźcem do aktywności na rzecz regionu i własnej grupy" (Szczurek-Boruta, Grabowska 2009: 46-47).

\section{Podsumowanie}

Celem podjętych rozważań było poznanie poczucia tożsamości narodowej osób w wieku późnej dorosłości żyjących w polskiej oraz czeskiej części Śląska Cieszyńskiego. Warunki polityczne, gospodarcze, społeczne i kulturowe południowej części pogranicza polsko-czeskiego wyznaczają proces kształtowania się tożsamości mieszkańców. Identyfikacja narodowa stanowi o kształtowaniu tożsamości narodowej. Dla osób w wieku późnej dorosłości przynależność do narodu przynosi poczucie bezpieczeństwa w dobie globalnych przemian. Ważnym aspektem kształtowania się tożsamości narodowej jest identyfikacja z regionem.

Wyniki przeprowadzonych badań własnych wskazują, że osoby w wieku późnej dorosłości zamieszkujące polską i czeską część Śląska Cieszyńskiego wykazują silne więzi $\mathrm{z}$ narodem. Utrwalanie identyfikacji narodowej $\mathrm{w}$ badanej grupie następuje - zgodnie ze stanowiskiem J. Nikitorowicza - na bazie dziedzictwa rodzinno-lokalnego, regionalnego. Wśród czynników decydujących o polskiej identyfikacji narodowej respondenci kolejno wskazywali: polskie obywatelstwo, miejsce urodzenia oraz pochodzenie. Wyniki przeprowadzonej analizy statystycznej - analizy skupień wskazały na ukonstytuowanie się dwóch struktur. W pierwszej subiektywnej/nieformalnej najwyższa współzależność istnieje między biegłym władaniem językiem polskim, polskim pochodzeniem współmałżonka, znajomością polskiej kultury i historii, pochodzeniem, miejscem urodzenia. Drugą strukturę (obiektywną/formalną) tworzą polskie obywatelstwo, miejsce zamieszkania.

Istotną rolę w kształtowaniu poczucia tożsamości narodowej odgrywa identyfikacja z regionem. Wśród wyznaczników tej identyfikacji badane osoby wskazały na: miejsce zamieszkania, znajomość kultury i historii Śląska Cieszyńskiego oraz miejsce urodzenia. 
Wśród czynników determinujących czeską identyfikację narodową osoby w wieku późnej dorosłości mieszkające w czeskiej części Śląska Cieszyńskiego wymieniły kolejno: czeskie obywatelstwo, miejsce urodzenia, znajomość czeskiej kultury i historii, biegłe władanie językiem czeskim, pochodzenie, miejsce zamieszkania oraz sentyment do kraju pochodzenia. Wyniki przeprowadzonej analizy statystycznej - analiza skupień wyznaczników poczucia czeskiej tożsamości narodowej wskazują na ukonstytuowanie się dwóch struktur. W pierwszej najwyższą współzależność odnotowano w odniesieniu do sentymentu, czeskiego pochodzenia współmałżonka oraz miejsca urodzenia. Drugą strukturę tworzą miejsce zamieszkania i czeskie obywatelstwo, znajomość czeskiej kultury i historii.

O identyfikacji z regionem osób w wieku późnej dorosłości mieszkających w czeskiej części Śląska Cieszyńskiego decydują kolejno: znajomość kultury i historii Śląska Cieszyńskiego, miejsce urodzenia, miejsce zamieszkania, pochodzenie, biegłe władanie gwarą, sentyment.

Uzyskane wyniki badań nie wskazują na związki między płcią, miejscem zamieszkania, wykształceniem respondentów a poczuciem tożsamości.

Podsumowując, tożsamość to konstrukt, który łączy elementy indywidualnego systemu wartości z wartościami danej grupy, do której jednostka należy. Identyfikacja narodowa jest znacząca w kształtowaniu się poczucia tożsamości osób w wieku późnej dorosłości. Można ją postrzegać przez pryzmat miejsca zakorzenienia, przynależności, a co za tym idzie poczucia bezpieczeństwa na tle zachodzących procesów globalnych.

\section{Bibliografia}

Bajkowski T. (2001) Tożsamość płciowa jako element tożsamości osobowej i społecznej w: Tożsamość osobowa a tożsamości społeczne, T. Bajkowski, K. Sawicki (red.), Białystok, Wydawnictwo „Trans Humana”, s. 74-84.

Bugajska B. (2012) Tożsamość człowieka w starości. Studium socjopedagogiczne, Szczecin, Wydawnictwo Naukowe Uniwersytetu Szczecińskiego.

Chlebowczyk J. (1983) O prawie do bytu małych i młodych narodów: kwestia narodowa i procesy narodotwórcze we wschodniej Europie środkowej dobie kapitalizmu (od schyłku XVIII do poczq̨tków XX w.), Warszawa-Kraków, Śląski Instytut Naukowy, PWN.

Erikson E. H. (1994) Identity and Life Cycle, New York-London, W. Norton \& Company.

Erikson E. H. (2000) Dzieciństwo i społeczeństwo, tłum. P. Hejmej, Poznań, Dom Wydawniczy REBIS. 
Ferguson G. A., Takane Y. (2004) Analiza statystyczna w psychologii i pedagogice, tłum. M. Zagrodzki, Warszawa, Wydawnictwo Naukowe PWN.

Frankfort-Nachmias C., Nachmias D. (2001) Metody badawcze w naukach społecznych, tłum. Elżbieta Hornowska, Poznań, Wydawnictwo Zysk i S-ka.

Guilford J. P. (1960) Podstawowe metody statystyki w psychologii i pedagogice, Warszawa, PWN.

Harwas-Napierała B., Trempała J. (2002) Psychologia rozwoju człowieka. Charakterystyka okresów życia człowieka, Warszawa, Wydawnictwo Naukowe PWN.

Jarymowicz M. (1989) Próba konceptualizacji pojęć tożsamość osobista - tożsamość społeczna: odrębność schematowa Ja-My-Inni jako atrybut tożsamości, „Studia Psychologiczne", 2: 73-84.

Jasiński Z., Kozłowska A. (1997) Tożsamość narodowa młodzieży na pograniczach, Opole, Wydawnictwo Uniwersytetu Opolskiego.

Kłoskowska A. (1996) Kultury narodowe u korzeni, Warszawa, PWN.

Kwiatkowska A. (1999) Tożsamość a społeczne kategoryzacje, Warszawa, Wydawnictwo Instytutu Psychologii PAN.

Kwieciński Z., Śliwerski B. (2004) Pedagogika. Podręcznik akademicki, Warszawa, Wydawnictwo Naukowe PWN.

Lewowicki T. (1994) Poczucie tożsamości narodowej młodzieży - stałość - zmienność w: Poczucie tożsamości narodowej młodzieży. Studium z pogranicza polsko-czeskiego, Lewowicki T. (red.), Cieszyn, Uniwersytet Śląski. Filia w Cieszynie, s. 127-135.

Mamzer H. (2001) Tożsamość kulturowa w świecie społeczno-regulacyjnej koncepcji kultury w: Kultury tradycyjne a kultura globalna. Konteksty edukacji międzykulturowej, J. Nikitorowicz, Sobecki, D. Misiejuk (red.), Białystok 2001, Wydawnictwo „Trans Humana", s. 77-88.

Misiak W. (2005) Tożsamość a przyszłość państw narodowych w: Tożsamość bez granic. Współczesne wyzwania, E. Budakowska (red.), Warszawa, Wydawnictwo Uniwersytetu Warszawskiego, s. 73-97.

Nikitorowicz J. (1995) Pogranicze. Tożsamość. Edukacja międzykulturowa, Białystok, Wydawnictwo „Trans Humana”.

Nikitorowicz J. (2000) Młodzież pogranicza kulturowego Białorusi, Polski, Ukrainy wobec integracji europejskiej, Białystok, Wydawnictwo „Trans Humana”. 
Nikitorowicz J. (2004) Idea zjednoczonej Europy - plany i aspiracje życiowe młodzieży na pograniczu wschodnim w: Plany życiowe młodzieży z terenów pograniczy, Z. Jasiński, T. Lewowicki, J. Nikitorowicz (red.), Opole, Wydawnictwo Uniwersytetu Opolskiego, s. 119-153.

Nikitorowicz J. (2007) Tożsamość w: Encyklopedia pedagogiczna XXI wieku, T. Pilch (red.), Warszawa, Wydawnictwo Akademickie „Żak”, s. 754-773.

Pilch T., Bauman T. (2001) Zasady badań pedagogicznych. Strategie ilościowe i jakościowe, Warszawa, Wydawnictwo Akademickie „Żak”.

Rubacha K. (2004) Nowe kategorie pojęciowe współczesnej teorii wychowania w: Pedagogika. Podręcznik akademicki, t. 2, Z. Kwieciński, B. Śliwerski (red.), Warszawa, Wydawnictwo Naukowe PWN, s. 59-67.

Rubacha K. (2008) Metodologia badań nad edukacją, Warszawa, Wydawnictwo AiP.

Sadowski A. (1997) Język w rodzinie, język ojczysty a tożsamość narodowa na polsko-białoruskim pograniczu w: Edukacja wobec wyznań edukacji międzykulturowej, J. Nikitorowicz (red.), Białystok, Wydawnictwo „Trans Humana”, s. 95-105.

Sobecki M. (2007) Kultura symboliczna a tożsamość, Białystok, Wydawnictwo „Trans Humana".

Suska M. (2001) Tożsamość a system wartości i postawy współczesnej młodzieży w: Tożsamość osobowa a tożsamości społeczne, T. Bajkowski, K. Sawicki (red.), Białystok, Wydawnictwo „Trans Humana”, s. 111-118.

Szczurek-Boruta A. (2009) Poczucie tożsamości kulturowej młodzieży - kilka tendencji, hipotez i uwag z zakresu edukacji międzykulturowej w: Tożsamość etniczna i kulturowa Śląska w procesie przemian, H. Rusek, A. Drożdż (red.), Wrocław-Cieszyn, Polskie Towarzystwo Ludoznawcze.

Szczurek-Boruta A. (2014) O przygotowaniu nauczycieli do pracy $w$ warunkach wielokulturowości - konteksty, opinie studentów, propozycje, Toruń, Wydawnictwo Adam Marszałek.

Szczurek-Boruta A. (2014) Trwałość i zmiana. Edukacja w środowisku lokalnym - w kręgu potrzeb i oczekiwań, „Studia Pedagogiczne”, t. LXVII, s. 40.

Szczurek-Boruta A., Grabowska B. (2009) Dynamika kształtowania się tożsamości młodzieży - ku tożsamości wzbogaconej w: Poczucie tożsamości i stosunek młodzieży do wybranych kwestii społecznych - studium z pogranicza polsko-czeskiego, T. Lewowicki, E. Ogrodzka-Mazur, A. Szczurek-Boruta (red.), Cieszyn-Warszawa-Toruń, Wydawnictwo Adam Marszałek. 
Szczypka-Rusz A. (2000) Współczesna rodzina cieszyńska. Kim sq rodzice? Kim chcieliby, żeby były ich dzieci - rzecz o tożsamości w: Rodzina wychowanie wielokulturowość, T. Lewowicki, J. Suchodolska (red.), Cieszyn, Uniwersytet Śląski - Filia w Cieszynie, Wyższa Szkoła Pedagogiczna ZNP w Warszawie, s. 48-55.

Tajfel H. (1972) Catégorisation sociale w: Introduction à la psychologie sociale, t. 1, S. Moscovici (red.), Paris, Larousse, s. 272-302.

Tołwińska B. (2001) Stereotypy płci a tożsamość indywidualna w: Tożsamość osobowa a tożsamości społeczne, T. Bajkowski, K. Sawicki (red.), Białystok 2001, Wydawnictwo „Trans Humana”, s. 67-73. 